\title{
Wpływ technologicznych parametrów napawania na geometrię napoin z brązu układanych na podłożu stalowym metodą MIG
}

\author{
Influence of technological parameters of MIG \\ surfacing on bronze padding weld geometry \\ on the steel substrate
}

\section{Streszczenie}

W artykule przedstawiono wyniki badań wpływu technologicznych parametrów napawania metodą MIG na geometrię napoin z brązu cynowego CuSn6 układanych na podłożu ze stali 45 o podwyższonej zawartości węgla. Badania przeprowadzono w dwóch etapach: w pierwszym wyznaczono zakresy parametrów napawania umożliwiające uzyskanie napoin o odpowiedniej jakości, a w drugim - stosując metodę planowania eksperymentu - określono wpływ wybranych parametrów na geometrię i głębokość wtopienia napoiny.

$\mathrm{Na}$ podstawie badań określono zakresy technologicznych parametrów napawania umożliwiających wykonanie napoin spełniających kryteria jakościowe. Wyznaczone funkcje aproksymujące pozwalają prognozować wymiary napoin w zależności od nastawionych parametrów.

\section{Abstract}

The paper presents the influence of technological parameters of MIG surfacing on the CuSn 6 bronze geometry of padding welds arranged on a substrate made of 45 steel with elevated coal ratio. The study was conducted in two phases: welding parameter ranges were determined to obtain the sufficient quality padding welds and using the method of experiment planning - the influence of some parameters on the geometry and depth of fusion penetration of the padding weld.

Based on the survey specified ranges of technological parameters of surfacing that meet quality criteria. Designated approximating functions make possible to predict the dimensions of welds according to preset parameters.

\section{Wstęp}

Napawanie brązem znajduje szerokie zastosowanie np. przy regeneracji powierzchni ślizgowych łożysk i suwaków różnych elementów maszyn, i urządzeń oraz powierzchni uszczelniających w przemysłowej armaturze wodnej lub parowej. Do badań wybrano dwa

Prof. dr hab. inż. Andrzej Skorupa, dr inż. Tomasz Góral - Akademia Górniczo-Hutnicza, Kraków. materiały przeznaczone do napawania o odmiennych właściwościach: brąz cynowy CuSn6 jako materiał dodatkowy i stal 45 jako materiał podstawowy. Typowymi zastosowaniami przedstawionego $\mathrm{w}$ pracy brązu CuSn6 są elementy łożysk ślizgowych i powierzchnie odporne na korozję. Stal 45 jest powszechnie wykorzystywana w produkcji części maszyn. W celu obniżenia kosztów napawania, a zwłaszcza kosztów materiałowych, konieczne jest ograniczenie do niezbędnego minimum zużycia napawanego brązu [1].

Podstawowym kryterium decydującym o możliwości zastosowania napawania brązem jest uzyskanie napoin o odpowiedniej jakości. Prawidłowo napawana 
warstwa z brązu powinna odpowiadać następującym kryteriom:

- lico napoiny powinno być gładkie o metalicznie rudawo-złotym zabarwieniu, bez widocznej szarej warstwy tlenków,

- napoina ciągła, bez porów, pęknięć i nadmiernie poszarpanych brzegów,

- niewielka głębokość wtopienia ułożonego ściegu musi być, aby uniknąć nadmiernego wymieszania brązu z podłożem.

Wymienione warunki prawidłowego napawania można spełnić, stosując metodę MIG. Proces napawania należy prowadzić z zastosowaniem niewielkiego podgrzania wstępnego w zakresie $60 \div 100^{\circ} \mathrm{C}$, żeby odparować wilgoć, w celu ograniczenia porowatości napoin. Zmniejszenie głębokości wtopienia (a tym samym wymieszania brązu z metalem podłoża) i jego utwardzenia wymaga, aby napięcie napawania $U_{n}$ i prąd napawania $I_{n}$ były małe przy jednoczesnym utrzymaniu stabilnego łuku. Na urządzenia spawalniczym nastawia się wymagane napięcie łuku, natomiast prąd napawania zadaje się przez ustawienie odpowiednio małej prędkości podawania drutu elektrodowego. Prędkość napawania $v_{n}$ ustala się tak, aby zapewnić stabilność prowadzenia procesu napawania i niewielką głębokość wtopienia [1].

\section{Ocena wpływu parametrów napawania na geometrię ściegu}

W badaniach wykorzystano metodę MIG, stosując brązowy drut elektrodowy CuSn6, o składzie chemicznym (\%): $6 \mathrm{Sn}, 0,2 \mathrm{P}$, reszta $\mathrm{Cu}$ (wg danych producenta drutu na podstawie DIN 1733) i właściwościach mechanicznych zestawionych w tablicy I. Średnica drutu wynosiła 1,2 mm. Jako materiał podłoża zastosowano stal 45 w postaci próbek o wymiarach 420x120x23 mm.

Badania nad doborem technologicznych parametrów napawania przeprowadzono na zmechanizowanym stanowisku badawczym, w celu zapewnienia powtarzalności wartości nastaw parametrów (rys. 1). W skład stanowiska wchodziły: półautomat spawalniczy OPTYMAG-501, uchwyt spawalniczy z dodatkową dyszą osłonową do wytworzenia poszerzonej strefy ochronnej gazu osłonowego, torowisko, po którym poruszał się wózek z zamocowaną na nim próbką do napawania, oraz komputerowy przyrząd do

Tablica I. Właściwości mechaniczne stopiwa uzyskanego z drutu elektrodowego CuSn6 wg danych producenta na podstawie DIN 1733

Table I. Mechanical properties of weld metal as CuSn6 wire acc. to producer data on base on DIN 1733

\begin{tabular}{|l|c|c|c|}
\hline \multicolumn{1}{|c|}{ Nazwa wielkości } & Oznaczenie & Jednostka & Wartość \\
\hline Umowna granica plastyczności & $\mathrm{R}_{\mathrm{p} 0.2}$ & $\mathrm{~N} / \mathrm{mm}^{2}$ & 140 \\
\hline Doraźna granica wytrzymałości & $\mathrm{R}_{\mathrm{m}}$ & $\mathrm{N} / \mathrm{mm}^{2}$ & 300 \\
\hline Wydłużenie względne & $\mathrm{A}_{5}$ & $\%$ & 20 \\
\hline Twardość Brinella & HB 10/1000 & daN/mm ${ }^{2}$ & 80 \\
\hline
\end{tabular}

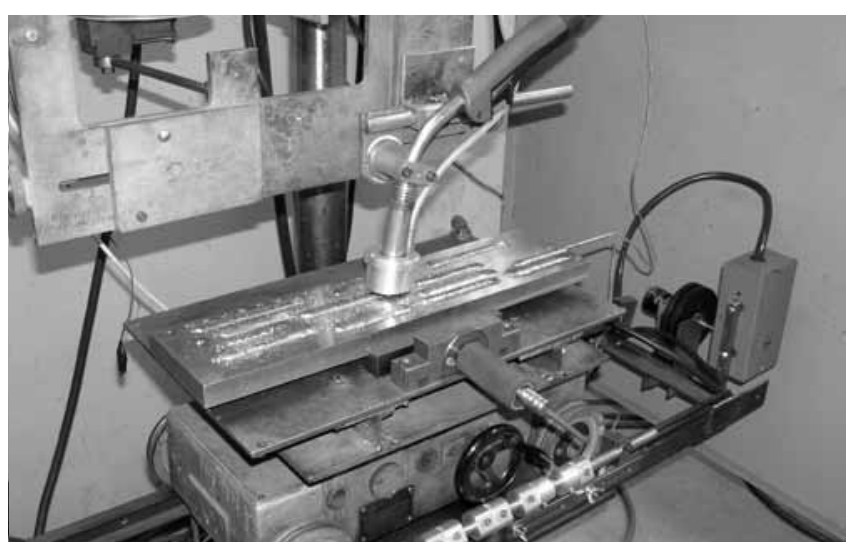

Rys. 1. Stanowisko badawcze

Fig. 1. The test stand

monitorowania procesu spawania. Wózek z zamocowaną blachą poruszał się z zadaną prędkością napawania. Bezstopniowy regulator napięcia umożliwiał osiągnięcie płynnej zmiany prędkości napawania. Komputerowy przyrząd do monitorowania procesu spawania umożliwiał ciągły pomiar i rejestrację takich parametrów napawania jak: natężenie prądu napawania $I_{n}$, napięcie łuku $U_{n}$, oraz prędkość napawania $v_{n}$. W badaniach przeprowadzono również pomiar temperatury przy użyciu termopary umieszczonej w otworze wywierconym w próbce, na której układane były napoiny. Parametry zarejestrowane podczas wykonywania ściegów umożliwiły późniejszą analizę przebiegu procesu napawania i ich konfrontację z uzyskanymi napoinami.

W celu ograniczenia liczby prób, badania wykonano w dwóch etapach: w pierwszym, wstępnym etapie, przeprowadzono serię prób, których celem było określenie korzystnych zakresów technologicznych parametrów napawania przy układaniu pojedynczego ściegu. Badania prowadzono przy stałych parametrach: odległość rurki prądowej od napawanego elementu $H=15 \mathrm{~mm}$, indukcyjność spawalniczego źródła prądu $5 \mathrm{wg}$ danych producenta, natężenie przepływu gazu osłonowego $Q=16 \mathrm{dm}^{3} / \mathrm{min}$. Gazem osłonowym był czysty argon. Pozostałe parametry, takie jak: prędkość podawania drutu elektrodowego $v_{e l}$, napięcie łuku $U_{n}$, prędkość napawania $v_{n}$, traktowano jako zmienne, które podczas badań należy określić. Prędkość podawania drutu elektrodowego mieściła się w zakresie 2,2 $\div 7,4 \mathrm{~m} / \mathrm{min}$, zaś napięcie łuku w granicach $15 \div 25$ V. Napoiny układano przy prędkościach napawania $3 \div 12 \mathrm{~mm} / \mathrm{s}$. Celem uzyskania napoin o jak najlepszej jakości utrzymywano temperaturę początkową podłoża w zakresie $60 \div 100^{\circ} \mathrm{C}$. Ocenę jakości napawanych ściegów wykonanych w pierwszym etapie badań przeprowadzono w oparciu o oględziny zewnętrzne, przyjmując kryteria podane poprzednio. Na tej podstawie określono parametry napawania mające praktyczne zastosowanie. Prędkość podawania drutu elektrodowego ustalono w zakresie $3,6 \div 7,4 \mathrm{~m} / \mathrm{min}$, napięcie łuku w granicach $21 \div 25 \mathrm{~V}$, a prędkość napawania przyjęto w przedziale $3 \div 9 \mathrm{~mm} / \mathrm{s}$. 

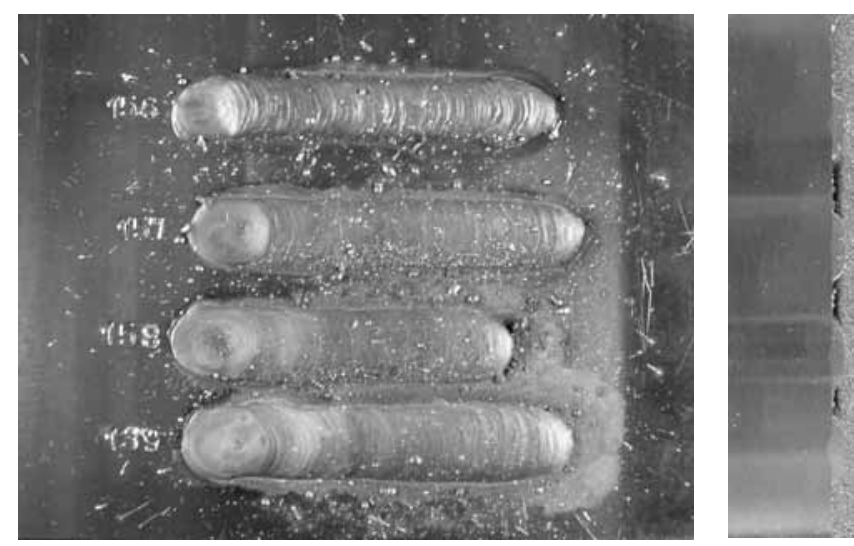

Rys. 2. Przykładowe ściegi i przekrój próbki po drugim etapie badań Fig. 2. Sample of beads and the cross-section after second stage of tests

Te wartości stanowiły bazę wyjściową do dalszych badań w ramach drugiego etapu.

W drugim etapie badań zależności pomiędzy wymiarami geometrycznymi: szerokością $b$, wysokością napoiny $\mathrm{h}$ oraz głębokością wtopienia $g$, a parametrami napawania, ze względu na dużą liczbę niezależnych wielkości wejściowych i koszty wykonywania doświadczenia, wyznaczono metodą planowania eksperymentu. były:

Parametrami wejściowymi do planu eksperymentu

- prędkość podawania drutu elektrodowego $v_{e l}, \mathrm{~mm}$,

- napięcie łuku $U_{n}, V$,

- prędkość napawania $v_{n}, \mathrm{~mm} / \mathrm{s}$.

Wartości parametrów stałych, tzn odległość rurki prądowej od napawanego elementu, indukcyjność spawalniczego źródła oraz wydatek gazu osłonowego przyjęto tak jak we wstępnym etapie badań.

Parametrami wyjściowymi dla planu eksperymentu, które należało wyznaczyć podczas badań, były:

- szerokość napoiny $b, \mathrm{~mm}$,

- wysokość napoiny $h, \mathrm{~mm}$,

- głębokość wtopienia g, mm.

Podczas planowania eksperymentu i analizy danych posługiwano się programem Cadex-Esdet 2.0, z którego wybrano plan Boxa-Benkena [2].

Widok ogólny przykładowych napoin i przekroju przeciętej blachy przedstawiono na rysunku 2 .

\section{Wyniki badań}

Podczas badań nieniszczących dokonano oględzin zewnętrznych, pomiaru szerokości $b$ i wysokości $h$ napoin, zaś głębokość wtopienia $g$ określono po poprzecznym przecięciu i wyszlifowaniu powierzchni czołowych próbek. Szerokość i wysokość ściegu zmierzono suwmiarką z głębokościomierzem o dokładności odczytu 0,05 mm. Głębokość wtopienia zmierzono mikroskopem warsztatowym MWD o wartości działki elementarnej 0,01 mm (rys. 3). Wyniki w postaci średniej

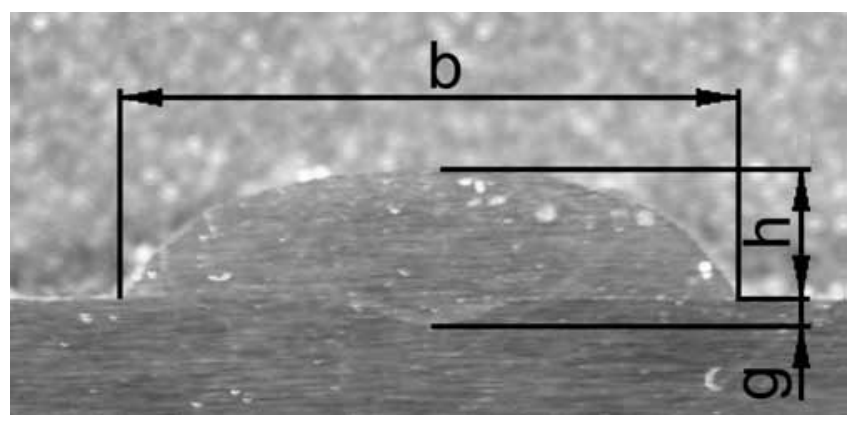

Rys. 3. Wymiary określające geometrię napoiny

Fig. 3. The dimensions of padding weld geometry

z pięciu pomiarów na długości ściegu zaprezentowano w tablicy II.

Otrzymane wyniki badań poddano analizie matematycznej za pomocą programu komputerowego Cadex-Esdet 2.0, wyznaczając następujące funkcje:

- $b=F_{1}\left(v_{e e^{\prime}} U_{n^{\prime}}, v_{n}\right)$,

- $h=F_{2}\left(v_{e l}, U_{n}^{n}, v_{n}\right)$,

- $g=F_{3}\left(v_{e p}, U_{n^{n}}, v_{n}\right)$.

Po wprowadzeniu wyników pomiarów wielkości wyjściowych (tabl. II) do programu komputerowego, przeprowadzono aproksymację funkcji i obiektu badań za pomocą wielomianów algebraicznych ze składnikami liniowymi, kwadratowymi oraz interakcją o postaci ogólnej:

$$
z=b_{0}+b_{1} x_{1}+\ldots+b_{i} x_{i}+b_{11} x_{1}^{2}+\ldots+b_{i i} x_{i}^{2}+b_{12} x_{1} x_{2}+b_{i-1} x_{i-1} x_{i}
$$

gdzie $b_{i}$ - współczynniki funkcji aproksymującej.

Tablica II. Wyniki pomiarów wymiarów geometrycznych i głębokości wtopienia pojedynczego ściegu dla poszczególnych układów planu eksperymentu

Table II. The results of geometry dimensions and depth of fusion penetration measurement for single bead in separate system of experiment plan

\begin{tabular}{|c|c|c|c|c|c|c|}
\hline \multirow{2}{*}{$\begin{array}{c}\text { Układ } \\
\text { planu }\end{array}$} & \multicolumn{3}{|c|}{$\begin{array}{c}\text { Technologiczne parametry } \\
\text { napawania }\end{array}$} & \multicolumn{2}{c|}{$\begin{array}{c}\text { Wymiary geometryczne } \\
\text { i głębokość wtopienia } \\
\text { pojedynczych ściegów }\end{array}$} \\
\cline { 2 - 7 } & $\begin{array}{c}v_{\text {el }} \\
\mathrm{m} / \mathrm{min}\end{array}$ & $\begin{array}{c}U_{n} \\
\mathrm{~V}\end{array}$ & $\begin{array}{c}v_{n} \\
\mathrm{~mm} / \mathrm{s}\end{array}$ & $\begin{array}{c}b \\
\mathrm{~mm}\end{array}$ & $\begin{array}{c}h \\
\mathrm{~mm}\end{array}$ & $\begin{array}{c}g \\
\mathrm{~mm}\end{array}$ \\
\hline 1 & 7,4 & 25 & 6 & 11,90 & 2,72 & 3,16 \\
\hline 2 & 3,6 & 25 & 6 & 8,13 & 1,73 & 0,66 \\
\hline 3 & 7,4 & 21 & 6 & 11,45 & 2,20 & 2,09 \\
\hline 4 & 3,6 & 21 & 6 & 7,49 & 2,08 & 0,31 \\
\hline 5 & 7,4 & 23 & 9 & 8,32 & 2,41 & 1,89 \\
\hline 6 & 3,6 & 23 & 9 & 6,63 & 1,72 & 0,13 \\
\hline 7 & 7,4 & 23 & 3 & 17,63 & 3,18 & 1,42 \\
\hline 8 & 3,6 & 23 & 3 & 11,00 & 2,80 & 0,44 \\
\hline 9 & 5,5 & 25 & 9 & 9,94 & 1,38 & 1,57 \\
\hline 10 & 5,5 & 21 & 9 & 8,95 & 1,55 & 0,92 \\
\hline 11 & 5,5 & 25 & 3 & 17,27 & 2,40 & 0,71 \\
\hline 12 & 5,5 & 21 & 3 & 13,75 & 2,92 & 0,53 \\
\hline 13 & 5,5 & 23 & 6 & 11,19 & 1,76 & 1,52 \\
\hline 14 & 5,5 & 23 & 6 & 10,55 & 2,09 & 1,97 \\
\hline 15 & 5,5 & 23 & 6 & 10,95 & 1,74 & 1,48 \\
\hline
\end{tabular}


Funkcje uproszczone utworzono przez wyeliminowanie współczynników nieistotnych za pomocą testu Studenta na poziomie istotności $\alpha=0,05$.

Postać równań matematycznych opisujących wielkości wyjściowe w funkcji technologicznych parametrów procesu napawania przedstawiono poniżej:

- szerokość napoiny b:

$b=10,8966667+2,00625\left(0,53 v_{e l}-2,89\right)+0,7\left(0,5 U_{n}-11,5\right)$ - 3,22625 (0,33-2) - 1,36833333 $(0,53 v-2,89)^{2}-0,0475$ $\left(0,53 v_{e l}-2,89\right)\left(0,5 U_{n}-11,5\right)-1,235\left(0,53 v_{e l}-2,89\right)\left(0,33 v_{n}-2\right)$ $+0,214166667\left(0,5 U_{n}-11,5\right)^{2}-0,6325\left(0,5 U_{n}-1,5\right)\left(0,33 v_{n}-2\right)$

$+1,36666667\left(0,33 v_{n}^{n}-2\right)^{2}$

- szerokość napoiny $b$ - funkcja uproszczona (dla poziomu istotności $\alpha=0,05$ ):

$b=11,0284615+2,00625\left(0,53 v_{a}-2,89\right)+0,7\left(0,5 U_{n}-11,5\right)$ $-3,22625\left(0,33 v_{n}-2\right)-1,38480769\left(0,53 v_{e l}-2,89\right)^{2}-1,235\left(0,53 v_{e l}\right.$ $-2,89)\left(0,33 v_{n}-2\right)+1,35019231\left(0,33 v_{n}-2\right)^{2}$

- wysokość napoiny $h$ :

$h=1,86333333+0,2725\left(0,53 v_{e l}-2,89\right)-0,065\left(0,5 U_{n}-11,5\right)$ $-0,53\left(0,33 v_{n}-2\right)+0,392083333\left(0,53 v_{e l}-2,89\right)^{2}+0,2175$ $\left(0,53 v_{e l}-2,89\right)(0,5 U-11,5)+0,0775\left(0,53 v_{e l}-2,89\right)\left(0,33 v_{n}-2\right)$ $-0,0729166667\left(0,5 U_{n}-11,5\right)^{2}+0,0875\left(0,5 U_{n}-11,5\right)\left(0,33 v_{n}-2\right)$ $+0,272083333\left(0,33 v_{n}-2\right)^{2}$

- wysokość napoiny $\mathrm{h}$ - funkcja uproszczona (dla poziomu istotności $\alpha=0,05$ ):

$h=2,17866667-0,53\left(0,33 v_{n}-2\right)$

- głębokość wtopienia g:

$g=1,65666667+0,8775\left(0,53 v_{e I}-2,89\right)+0,28125\left(0,5 U_{n}-11,5\right)$

$+0,17625\left(0,33 v_{n}-2\right)-0,0320833333\left(0,53 v_{e l}-2,89\right)^{2}$

$+0,18\left(0,53 v_{e}-2,89\right)\left(0,5 U_{n}-11,5\right)+0,195\left(0,53 v_{e t}-2,89\right)\left(0,33 v_{n}-2\right)$

- 0,0695833333 $\left(0,5 U_{n}-11,5\right)^{2}+0,1175\left(0,5 U_{n}^{e l}-11,5\right)\left(0,33 v_{n}^{n}-2\right)$

$-0,654583333\left(0,33 v_{n}-2\right)^{2}$

- głębokość wtopienia $g$ - funkcja uproszczona (dla poziomu istotności $\alpha=0,05$ ):

$g=1,59857143+0,8775\left(0,53 v_{e l}-2,89\right)-0,647321429\left(0,33 v_{n}-2\right)^{2}$

Równania te $z$ dużym przybliżeniem pozwalają na obliczenie wielkości wyjściowych w zależności od czynników wejściowych w całym badanym zakresie technologicznych parametrów napawania. Próby dalszych uproszczeń równań dla poziomu istotności $\alpha=0,1$ powodowały powstawanie nadmiernych różnic pomiędzy wartościami wyliczonymi ze wzorów a wymiarami rzeczywistymi napoin.

Wykresy wyżej wyznaczonych funkcji pokazano na kolejnych rysunkach $4 \div 9$.

Analizując otrzymane zależności funkcyjne i wykresy, można wywnioskować, że:

- Dla funkcji uwzględniającej wszystkie współczynniki szerokość napoiny $b$ mieści się $\mathrm{w}$ zakresie $6,9 \div 18,9 \mathrm{~mm}$. Jej szerokość rośnie znacząco ze wzrostem prędkości podawania drutu elektrodowego $v_{e l}$ (rys. 4). Jedynie dla prędkości podawania drutu elektrodowego powyżej $6 \mathrm{~m} / \mathrm{min}$ i prędkości napawania $9 \mathrm{~mm} / \mathrm{s}$ można zaobserwować nieznaczne zmniejszenie szerokości napoiny. Może to być spowodowane tym, że w czasie napawania przy dużych prędkościach napawania i podawania drutu elektrodowego napoina nie zdąży się rozpłynąć, ulegając wcześniej zastygnięciu. Zmniejszenie

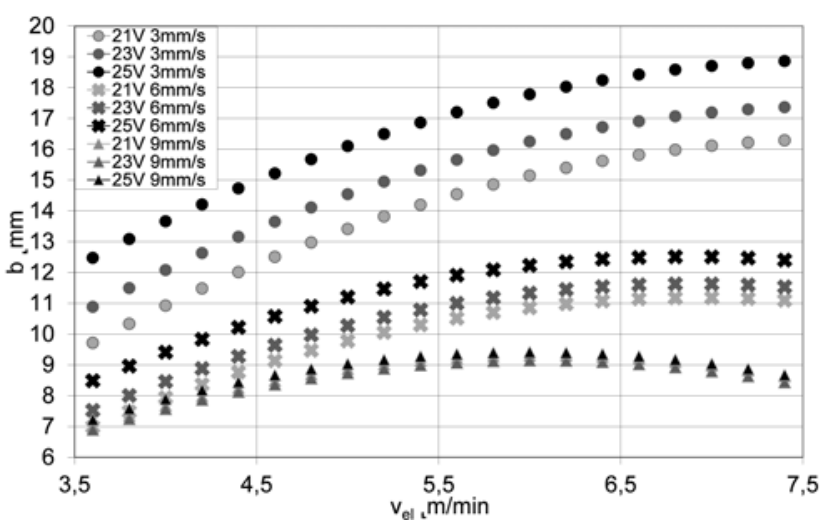

Rys. 4. Wpływ napięcia $U_{n}$ i prędkości podawania drutu elektrodowego $v_{e l}$ na szerokość napoin $b$

Fig. 4. The influence of voltage $U_{n}$ and wire feed rate $v_{e l}$ on padding weld width $b$

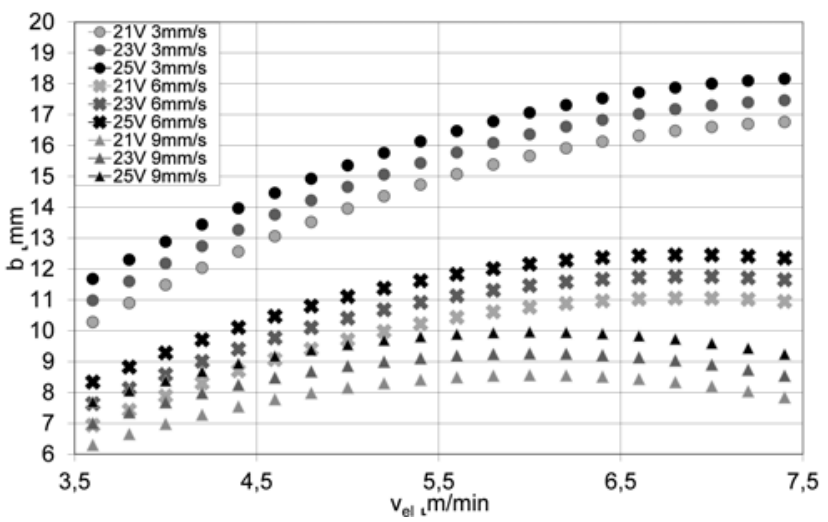

Rys. 5. Wpływ napięcia $U_{n}$ i prędkości podawania drutu elektrodowego $v_{e}$ na szerokość napoin $b$ dla funkcji uproszczonej

Fig. 5. The influence of voltage $U_{n}$ and wire feed rate $v_{e l}$ on padding weld width $b$ for simplified function

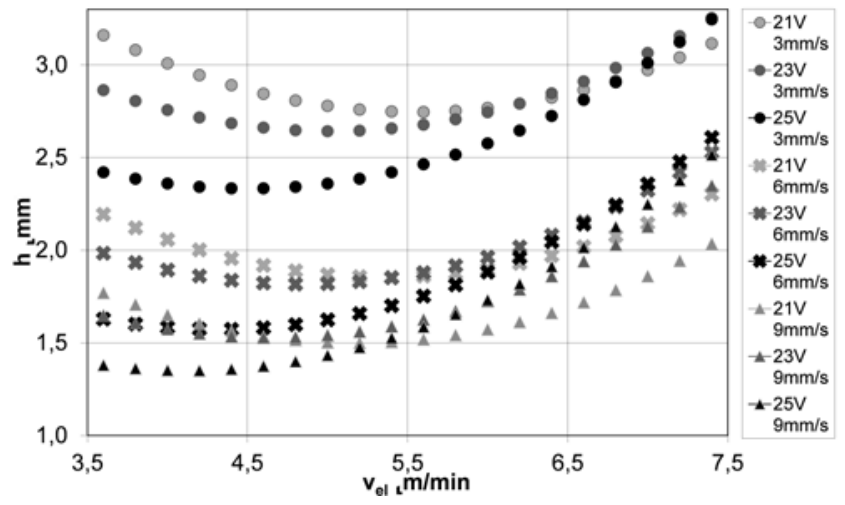

Rys. 6. Wpływ napięcia $U_{n}$ i prędkości podawania drutu elektrodowego $v_{e l}$ na wysokość napoin $h$

Fig. 6. The influence of voltage $U_{n}$ and wire feed rate $v_{e l}$ on padding weld high $h$ 
prędkości napawania $v_{n}$ przy niezmienionych pozostałych parametrach napawania znacznie zwiększa szerokość napoiny. Zwiększenie napięcia daje szerszą napoinę przy mniejszych prędkościach napawania (3 i $6 \mathrm{~mm} / \mathrm{s}$ ), zaś przy prędkości $9 \mathrm{~mm} / \mathrm{s}$ jest to zmiana minimalna. Dla funkcji uproszczonej dla poziomu istotności $\alpha=0,05$ przebieg zmian szerokości jest podobny jak w powyższym opisie (rys. 5). Jedynie można zauważyć silniejszy wpływ napięcia

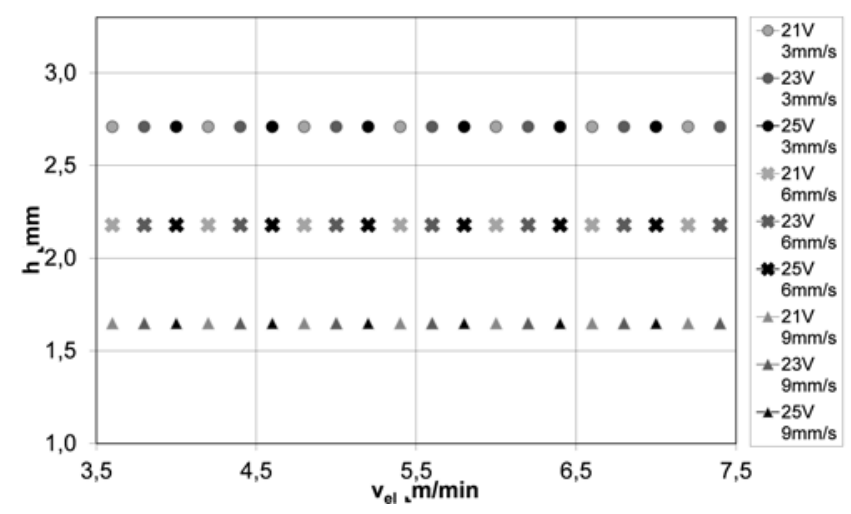

Rys. 7. Wpływ napięcia $U_{n}$ i prędkości podawania drutu elektrodowego $v_{\text {el }}$ na wysokość napoin $h$ dla funkcji uproszczonej

Fig. 7. The influence of voltage $U_{n}$ and wire feed rate $v_{e l}$ on padding weld high $h$ for simplified function

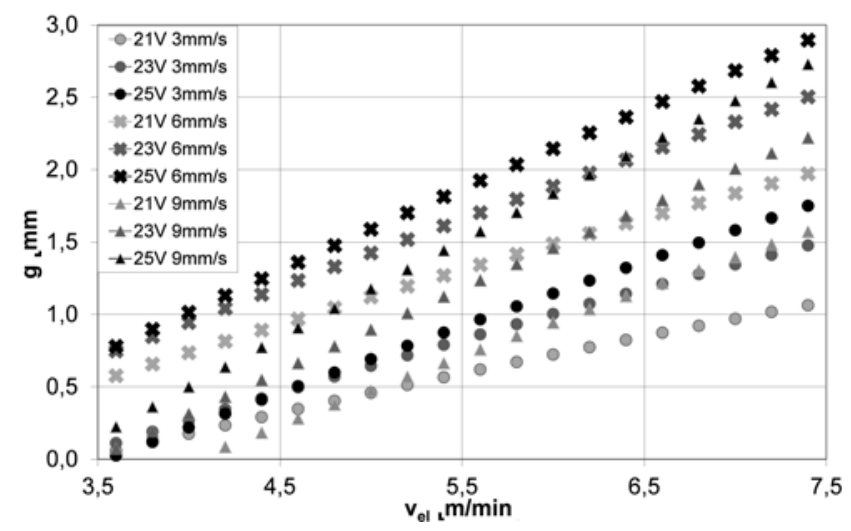

Rys. 8. Wpływ napięcia $U_{n}$ i prędkości podawania drutu elektrodowego $v_{\text {el }}$ na głębokość wtopienia $g$

Fig. 8. The influence of voltage $U_{n}$ and wire feed rate $v_{\text {el }}$ on the depth of fusion penetration of padding weld $\mathrm{g}$ for simplified function

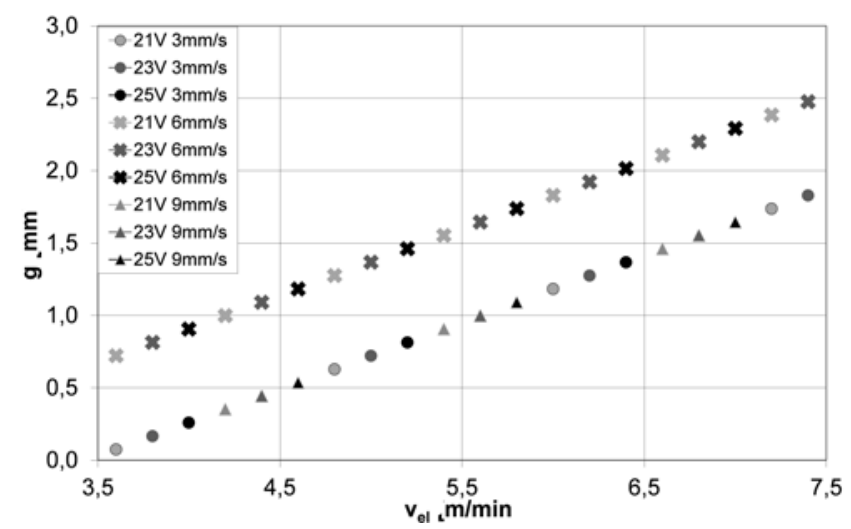

Rys. 9. Wpływ napięcia $U_{n}$ i prędkości podawania drutu elektrodowego $v_{e l}$ na głębokość wtopienia $g$ dla funkcji uproszczonej

Fig. 9. The influence of voltage $U_{n}$ and wire feed rate $v_{e l}$ on the depth of fusion penetration of padding weld $g$ for simplified function na szerokość napoiny dla wyższych prędkości napawania.

- Wysokość napoin $h$ wynosi od 1,4 do $3,3 \mathrm{~mm}$ dla funkcji ze wszystkimi współczynnikami (rys. 6). Zwiększenie prędkości podawania drutu elektrodowego powoduje w lewej części wykresu zmniejszenie wysokości napoiny, by w jego dalszej części wywołać jej wzrost. Napięcie ma wpływ na wysokość napoiny podobny jak prędkość podawania drutu elektrodowego. Dla funkcji uwzględniającej wszystkie współczynniki większy wpływ na wysokość napoiny $h$ ma tylko prędkość napawania $v_{n}$, a dla funkcji uproszczonej jest jedynym parametrem wpływającym na nią (rys. 7).

- Głębokość wtopienia $g$ wynosi do $2,9 \mathrm{~mm}$ (rys. 8). Wzrost prędkości podawania drutu elektrodowego $v_{\text {el }}$ znacząco wpływa na zwiększenie głębokości wtopienia $g$, zarówno dla funkcji ze wszystkimi współczynnikami, jak i dla funkcji uproszczonej (rys. 9). Zmiany napięcia $U_{n}$ w niewielkim stopniu mają wpływ na głębokość wtopienia g dla obu funkcji, szczególnie przy małych prędkościach $v_{e l}$. Największe wtopienie można osiągnąć dla prędkości $6 \mathrm{~mm} / \mathrm{s}$ niezależnie od wartości napięcia. Prędkości napawania 3 i $9 \mathrm{~mm} / \mathrm{s}$ stosunkowo niewiele różnią się wpływem na głębokość wtopienia, zwłaszcza dla mniejszych prędkości podawania drutu elektrodowego. Dla funkcji uproszczonej obie prędkości napawania (3 i $9 \mathrm{~mm} / \mathrm{s}$ ) mają takie same oddziaływanie na głębokość wtopienia. W przypadku większej prędkości napawania krótszy jest czas oddziaływania łuku na materiał podłoża i tym samym mniejszy jest przetop. Dla niższej prędkości napawania mniejszą głębokość wtopienia autorzy pracy tłumacza odmiennym mechanizmem formowania ściegu napoiny w stosunku do napoin wykonywanych przy wyższych prędkościach napawania [3]. W napoinie o dużej objętości (mniejsza prędkość napawania) jeziorko ciekłego metalu krzepnie z bardzo małą prędkością, powodując podpływanie ciekłego metalu pod łuk elektryczny. Jeziorko ciekłego metalu dużej objętości tłumi siłę dynamiczną łuku elektrycznego oraz oddziaływanie łuku na napawane podłoże, dzięki czemu możliwe jest zmniejszenie udziału podłoża i głębokości wtopienia.

Dalszą część eksperymentu odnoszącą się nie do pojedynczych ściegów, ale do warstwy napoiny przeprowadzono z zastosowaniem parametrów napawania, które zapewniają wysoką wydajność napawania przy małym udziale materiału podłoża w napoinie wynoszącym ok. $5 \%$. Parametry takie wybrano ze względu na efektywność wykorzystania brązu i jak najmniejszą jego zawartość w materiale podłoża. Wytypowane parametry napawania na podstawie wyników z poprzedniego etapu badań zaprezentowano w tablicy III.

Podziałkę napawania, czyli wartości zakładki ściegu nałożonego na ścieg wcześniejszy, przyjęto w zakresie $0,25 \div 0,6$ (rys. 10b), czyli $w$ nieco szerszym przedziale niż zaleca to [4]. $\mathrm{Na}$ 
Tablica III. Zestawienie technologicznych parametrów napawania zastosowanych do układania ściegów w warstwach

Table III. Surfacing technological parameters for bead running in the layers

\begin{tabular}{|l|c|c|}
\hline \multicolumn{1}{|c|}{$\begin{array}{c}\text { Nazwa technologicznego } \\
\text { parametru napawania }\end{array}$} & Symbol & Wartość \\
\hline Prędkość podawania drutu elektrodowego & $v_{e l}$ & $5,5 \mathrm{~m} / \mathrm{min}$ \\
\hline Napięcie łuku & $U_{n}$ & $23 \mathrm{~V}$ \\
\hline Prędkość napawania & $v_{n}$ & $3 \mathrm{~mm} / \mathrm{s}$ \\
\hline $\begin{array}{l}\text { Odległość rurki prądowej } \\
\text { od napawanego elementu }\end{array}$ & $H$ & $18 \mathrm{~mm}$ \\
\hline Indukcyjność spawalniczego źródła prądu & $L$ & 5 \\
\hline Rodzaj gazu osłonowego & $A r$ & $\operatorname{argon~} 100 \%$ \\
\hline Przepływ gazu osłonowego & $Q$ & $16 \mathrm{dm}^{3} / \mathrm{min}$ \\
\hline $\begin{array}{l}\text { Temperatura wstępnego podgrzania } \\
\text { (międzyściegowa) }\end{array}$ & $T_{o}$ & $60 \div 200^{\circ} \mathrm{C}$ \\
\hline
\end{tabular}

rysunku 10a pokazano przekrój próbki ze ściegami wykonanymi przy różnych podziałkach w tym zakresie.

W dziesięciu przekrojach porzecznych próbek dokonano $z$ dokładnością do $0,01 \mathrm{~mm}$ pomiarów głębokości wrębów pomiędzy ściegami w stosunku do powierzchni napawanej blachy $h$, posługując się mikroskopem warsztatowym MWD (rys. 10b). W tablicy IV podano minimalną wartość $h_{\min }$ zmierzoną we wszystkich przekrojach dla danej podziałki.

Wyniki w tablicy IV i rysunek 10 wskazuja, że podziałki w zakresie $0,25 \div 0,35$ są zbyt małe i pomiędzy ściegami powstaje dość duże wgłębienie. Natomiast dla podziałki 0,6 pojawił się nadlew, który również nie jest korzystny, gdyż przy obróbce mechanicznej, podczas wyrównywania warstwy ułożonych ściegów zostanie zebrany, powodując straty brązu. Uwzględniając otrzymane wyniki, kolejne próbki wykonano z podziałką 0,5 (rys. 11).

Najmniejsza wartość wysokości wrębu $h_{\min }$ wynosiła 2,17 mm. Wrąb ten znajdował się obok pierwszej napoiny w warstwie (na rys. 11 pierwsza z prawej). Pozostałe wartości wysokości wrębu $h_{\min }$ mieściły się w zakresie 2,45 $\div 3,04 \mathrm{~mm}$. Największa głębokość wtopienia g wynosiła $1,15 \mathrm{~mm}$ również dla pierwszej napoiny $\mathrm{w}$ warstwie. Pozostałe głębokości wtopienia należały do zakresu $0,34 \div 0,70 \mathrm{~mm}$. Po końcowej obróbce
Tablica IV. Minimalne wysokości wrębów między ściegami w zależności od wielkości podziałki napawania

Table IV. Minimum high of notching between beads In the function of run

\begin{tabular}{|l|c|c|c|c|}
\hline Wartość podziałki $b$ & 0,25 & 0,3 & 0,35 & 0,6 \\
\hline $\begin{array}{l}\text { Wysokość wrębu pomiędzy } \\
\text { ściegami } h_{\min }, \mathrm{mm}\end{array}$ & 1,09 & 2,21 & 2,58 & $\begin{array}{c}\text { nad- } \\
\text { lew }\end{array}$ \\
\hline
\end{tabular}
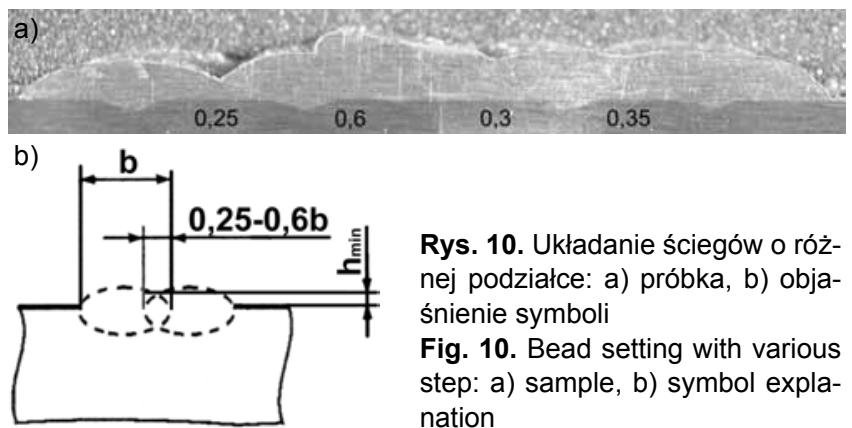

Rys. 10. Układanie ściegów o różnej podziałce: a) próbka, b) objaśnienie symboli

Fig. 10. Bead setting with various step: a) sample, b) symbol explanation

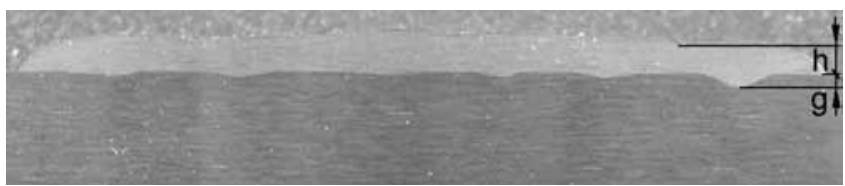

Rys. 11. Próbka z napoiną jednowarstwową (podziałka napawania 0,5 ) Fig. 11. The sample with single-layer pudding weld (surfacing run 0.5 )

mechanicznej grubość warstwy napawanej może sięgać wartości ok. $2 \mathrm{~mm}$.

Największą głębokość wtopienia dla pierwszego ściegu napoiny w warstwie nakładanej na materiał podłoża można tłumaczyć bezpośrednim oddziaływaniem łuku na ten materiał. Dalsze ściegi mają mniejszą głębokość wtopienia ze względu na częściowe oddziaływanie łuku na napoinę wykonaną wcześniej. Głębsze przetopienie podłoża przez pierwszy ścieg jest też powodem wystąpienia mniejszej wysokości $h_{\min }$ dla wrębu znajdującego się w sąsiedztwie tego ściegu. Wyeliminowanie tego zjawiska jest możliwe przez wykonanie pierwszego ściegu z mniejszym natężeniem i napięciem łuku [4].

\section{Wnioski}

Na podstawie przeprowadzonych badań można stwierdzić zależność wymiarów geometrycznych i jakości wykonywanych napoin od technologicznych parametrów napawania. Wyznaczone zakresy tych parametrów pozwalają wykonywać napoiny spełniające kryteria jakościowe, a funkcje aproksymujące umożliwiają prognozowanie wymiarów ściegu w zależności od nastawionych parametrów.

Stosując przygotowanie powierzchni przez obróbkę skrawaniem, oczyszczanie i odtłuszczanie oraz wstępne podgrzanie podłoża do temperatury $60 \div 100^{\circ} \mathrm{C}$, a także prowadząc napawanie w zakresie prędkości podawania drutu elektrodowego $3,6 \div 7,4 \mathrm{~m} / \mathrm{min}$, napięcia łuku $21 \div 25 \mathrm{~V}$ i prędkości napawania $3 \div 9 \mathrm{~mm} / \mathrm{s}$, można uzyskać ściegi spełniające odpowiednie kryteria jakościowe. Pozostałe technologiczne parametry napawania powinny wynosić: wylot drutu elektrodowego $15 \mathrm{~mm}$ i przepływ gazu osłonowego (argon) $16 \mathrm{dm}^{3} / \mathrm{min}$. Zastosowanie ww. parametrów przedstawionych w tablicy III i podziałki napawania wynoszącej 0,5 umożliwia uzyskanie napoin o minimalnym wymieszaniu z materiałem podłoża i grubości warstwy napawanej ok. $2 \mathrm{~mm}$ po końcowej obróbce mechanicznej. 


\section{Literatura}

[1] Skorupa A., Krawczyk S., Góral T.: Badania właściwości tribologicznych napoin wielowarstwowych z brązu CuSn6 nakładanych na podłoże stalowe metodą MIG. Przegląd Spawalnictwa 8/2007.

[2] Polański Z.: Planowanie doświadczeń w technice. PWN, Warszawa 1984.
[3] Klimpel A., Czupryński A., Rzeźnikiewicz A.: Wpływ kierunku i kąta pochylenia palnika GMA na jakość i właściwości technologiczne napoin wykonanych drutem cermetalowym. Przegląd Spawalnictwa 4-5/2005.

[4] Klimpel A.: Napawanie i natryskiwanie cieplne. Technologie. WNT, Warszawa 2000.

\section{Laureaci XI Jubileuszowej Edycji Konkursu o Nagrodę i Dyplom Prezesa SIMP na najlepszą pracę dyplomową o profilu mechanicznym - rok akademicki 2009/2010}

17 listopada 2011 r. odbyło się uroczyste spotkanie kierownictwa SIMP z laureatami XI Jubileuszowej Edycji Ogólnopolskiego Konkursu o Nagrodę i Dyplom Prezesa SIMP na najlepszą pracę dyplomową o profilu mechanicznym, obronioną w państwowej wyższej uczelni technicznej, pod Patronatem Honorowym pani Barbary Kudryckiej - Minister Nauki i Szkolnictwa Wyższego. Podczas uroczystości wręczono laureatom dyplomy, książki, nagrody pieniężne ufundowane przez Zarząd Główny SIMP, puchary ufundowane przez Ministerstwo Nauki i Szkolnictwa Wyższego oraz nagrody specjalne dla najlepszej pracy konstrukcyjnej ufundowane przez Urząd Dozoru Technicznego.

Nagrody wręczyli: prof. Jan Pilarczyk - przewodniczący Komisji Konkursowej, dr inż. Andrzej Ciszewski - prezes SIMP, Kazimierz Łasiewicki - sekretarz generalny SIMP i Robert Chudzik - wicedyrektor Zespołu Koordynacji Inspekcji Urzędu Dozoru Technicznego.

Prace nadesłane do XI edycji Konkursu przez absolwentów Politechnik: Wrocławskiej, Poznańskiej, Gdańskiej, Radomskiej, Lubelskiej, Łódzkiej, Warszawskiej, Śląskiej oraz Akademii Techniczno-Humanistycznej w Bielsku-Białej i Wojskowej Akademii Technicznej w Warszawie, wyróżniały się wysokim poziomem merytorycznym. Dlatego też Komisja Konkursowa poświęciła wiele czasu, by wyłonić najlepsze z nich, zasługujące na nagrody i wyróżnienia.

Rozstrzygnięcie XI Edycji Konkursu odbyło się na posiedzeniu Głównej Komisji Konkursowej przy ZG SIMP w dniu 15 września 2011 r. pod przewodnictwem prof. Jana Pilarczyka i przedstawia się następująco:

\section{Prace nagrodzone}

I miejsce: Kamil ŚPIEWAK - Opracowanie technologii spawania laserowego mechanizmu siedzenia samochodowego. Promotor: dr hab. inż. Zbigniew Mirski, prof. nadzw. PWr - Politechnika Wrocławska, Wydział Mechaniczny, Wrocław. II miejsce: Jakub Łukasz ROJEWSKI - Wyznaczenie całkowitej sprawności motosprężarki Cooper-Bessemer GMVH-12 pracującej w tłoczni gazu. Promotor: dr hab. inż. Tomasz Ignacy Dobski - Politechnika Poznańska, Wydział Maszyn Roboczych i Transportu, Poznań.
II miejsce: Marta WALCZAK - Badania geometrii kanału gazodynamicznego przy spawaniu wiązką laserową metodą z głębokim wtopieniem. Promotor: dr inż. Wojciech Kiełczyński - Politechnika Gdańska, Wydział Mechaniczny, Gdańsk.

III miejsce: Paweł BARANOWSKI - Badania numeryczne zjawisk termomechanicznych występujących na powierzchni ciernej tarczy hamulcowej. Promotor: dr inż. Jerzy Małachowski - Wojskowa Akademia Techniczna w Warszawie, Wydział Mechaniczny, Warszawa.

III miejsce: Marcin ZALEWSKI - Projekt przenośnika wibracyjnego orientującego opaski kotew mechanicznych. Promotor: dr hab. inż. Stanisław Krawiec, prof. nadzw. PWr - Politechnika Wrocławska, Wydział Mechaniczny, Wrocław.

wyróżnienie: Michał SIRAK - Ocena wpływu starzenia na destrukcje powłok lakierniczych samochodów. Promotor: $d r$ hab. inż. Danuta Kotnarowska - Politechnika Radomska, Wydział Mechaniczny, Radom.

wyróżnienie: Marcin WALOTKA - Technologia obróbki kostki przyłączeniowej wymiennika ciepła i konstrukcja uchwytu mocującego. Promotor: dr hab. inż. Roman Staniek, prof. PP - Politechnika Poznańska Wydział Budowy Maszyn i Zarządzania, Poznań

wyróżnienie: Marcin JAMONTT - Ocena podatności cieplnej materiału ceramicznego na pękanie. Promotor: dr Hanna de Sas Stupnicka - Politechnika Lubelska, Wydział Mechaniczny, Lublin.

\section{Nagrody specjalne Urzędu Dozoru Technicznego}

1. Paweł Baranowski - Badania numeryczne zjawisk termomechanicznych występujących na powierzchni ciernej tarczy hamulcowej. Promotor: dr inż. Jerzy Małachowski, Wojskowa Akademia Techniczna w Warszawie, Wydział Mechaniczny.

2. Marcin Jamontt - Ocena podatności cieplnej materiału ceramicznego na pękanie. Promotor: dr Hanna de Sas Stupnicka, Politechnika Lubelska, Wydział Mechaniczny.

3. Michał Sirak - Ocena wpływu starzenia na destrukcję powłok lakierniczych samochodów. Promotor: dr hab. inż. Danuta Kotnarowska, Politechnika Radomska, Wydział Mechaniczny. 